\title{
EVALUASI DAMPAK BERLAKUNYA PP NO. 11 TAHUN 2010 TENTANG PENERTIBAN DAN PENDAYAGUNAAN TANAH TERLANTAR TERHADAP KEBIJAKAN PENGELOLAAN TANAH PERTANIAN DI KABUPATEN TASIKMALAYA
}

\author{
Ida Nurlinda ${ }^{1}$, Yani Pujiwati ${ }^{2}$, dan Marenda Ishak $\mathbf{S}^{3}$ \\ ${ }^{1,2}$ Instansi Fakultas Hukum Unpad, ${ }^{3}$ Instansi Fakultas Pertanian Unpad \\ Email : marenda_07@yahoo.co.id
}

\begin{abstract}
ABSTRAK. Penetapan UU No 41 tahun 2009 tentang Perlindungan Lahan Pertanian Pangan Berkelanjutan bertujuan untuk mencegah terjadinya alih fungsi tanah pertanian. Data BPS (2010), menunjukkan bahwa 27 ribu hektar tanah pertanian dialihfungsikan untuk kepentingan non pertanian. Berdasarkan hal tersebut, UU No. 41/2009 diharapkan mampu menjadi instrumen pengendalian dalam pemanfaatan tanah. Di lain pihak, munculnya PP No 11 tahun 2010 tentang penertiban dan pendayagunaan tanah terlantar berpotensi terhadap meningkatnya alih fungsi tanah pertanian. Penelitian ini bertujuan untuk : (1) mengevaluasi dampak berlakunya PP No 11 tahun 2010 berkaitan dengan kebijakan pengelolaan tanah pertanian; (2) Menjadi dasar dalam perumusan aturan pelaksanaan PP ; (3) mengkaji efektifitas pelaksanaan program terkait oleh dinas lainnya, dalam rangka mewujudkan perlindungan lahan pertanian pangan berkelanjutan. Evaluasi dilakukan dengan metode analisis yuridis empiris. Selanjutnya, dilakukan kajian evaluasi lahan dalam rangka menilai produktivitas lahan pertanian dan penyebab rendahnya produktivitas lahan dari tanahtanah yang terindikasi terlantar. Hasil penelitian menunjukkan bahwa; PP 11/2010 ini tidak efektif dalam melakukan pemberdayaan dan penertiban tanah terlantar. Kedua, kordinasi dalam pelaksanaan PP dinilai kurang memadai antar sesama dinas-dinas yang terkait. Ketiga, perlu dilakukan penelitian guna membuat aturan pelaksanaan terhadap penertiban dan pendayagunaan tanah yang lebih adil dan berkelanjutan. Kata kunci : Tanah terlantar, lahan pertanian, pendayagunaan tanah
\end{abstract}

\section{EVALUATION OF IMPACT APPLICABILITY PP NO. 11/2010 ON THE CONTROL AND UTILIZATION OF WASTELANDS FOR POLICY OF AGRICULTURAL LAND MANAGEMENT ON TASIKMALAYA}

\begin{abstract}
Determination Act No. 41 of 2009 on the protection of agricultural land sustainable food to prevent the transfer function of agricultural land. BPS Data (2010), showed that 27 thousand acres of farmland converted to non-agricultural interests. Accordingly, Law no. 41/2009 is expected to be instrumental in controlling the use of land. On the other hand, the emergence of Government Regulation No. 11 of 2010 concerning the control and utilization of wastelands over the functions of the potential for increased agricultural land. This study aims to: (1) evaluate the impact of enactment of Law No. 11 of 2010 relating to agricultural land management policy, (2) become the basis for the formulation of the rules implementing PP, (3) assess the effectiveness of related programs by other agencies, in order to realize the protection sustainable food agriculture. The evaluation is done by the method of empirical legal analysis. Furthermore, land evaluation studies conducted in order to assess the productivity of agricultural land and the low productivity of the soils indicated abandoned. The results showed that: PP 11/2010 is not effective in controlling empowerment and wasteland. Second, coordination in the implementation of PP assessed inadequate interpersonal related agencies. Third, research needs to be done to make rules implementing the control and utilization of the land fairer and more sustainable.
\end{abstract}

Keyword : Wastelands, agricultural land, utilization of land 


\section{PENDAHULUAN}

Berdasarkan hasil identifikasi BPN Tahun 2011, luas lahan yang terindikasi terlantar di Indonesia terdapat sekitar 7,3 juta hektar tanah ${ }^{1}$; sedangkan tanah yang sudah dinyatakan terlantar adalah 459 bidang $^{2}$, yang luasnya mencakup 4,8 juta hektar. Permasalahan tanah terlantar banyak disebabkan karena ijin pemanfaatan tanah yang tidak sesuai dengan peruntukannya. Hal ini karena proses spekulasi tanah yang dikuasai oleh pengusaha dengan beragam izin untuk keuntungan semata.

Hal ini jelas sangat ironis dan menciderai perasaan keadilan rakyat kecil yang tidak memiliki lahan. Di satu sisi kebutuhan tanah sangat tinggi namun di sisi lain sebagian orang yang memiliki hak-hak atas tanah, tidak memanfaatkan tanahnya dengan baik dan optimal. Selain tidak adil, penelantaran tanah menghilangkan potensi ekonomi dan sosial dari tanah itu sendiri, dan menghilangkan pula akses sosial ekonomi masyarakat, terutama akses petani terhadap tanah.

Kondisi banyaknya jumlah dan luas tanah yang terindikasi terlantar dan/atau terlantar ini semakin diperparah dengan banyaknya tanah pertanian yang beralih fungsi dari lahan pertanian ke penggunaan/pemanfaatan non pertanian seperti pembangunan sektor perumahan, industri, jasa, infrastruktur dan kegiatan ekonomi lainnya. Kegiatan-kegiatan pembangunan ini telah memicu terjadinya alih fungsi lahan pertanian secara besar-besaran dan tidak terkendali. Data Ditjen Pengelolaan Lahan dan Air (PLA) Kementerian Pertanian pada Tahun 2005 menunjukkan bahwa setiap tahun sekitar 187.720 Ha sawah telah beralih fungsi ke penggunaan non pertanian, terutama di Pulau Jawa ${ }^{3}$.

1 Penjelasan Pasal 4 ayat (1), PP No. 11 Tahun 2010 tentang Penertiban dan pendayagunaan Tanah Terlantar, Tanah yang terindikasi tanah terlantar adalah tanah hak atau dasar penguasaan atas tanah yang tidak diusahakan, tidak dipergunakan atau tidak dimanfaatkan sesuai dengan keadaan atau sifat dan tujuan pemberian hak atau sifat dan tujuan pemberian hak atau dasar penguasaannya yang belum dilakukan identifikasi dan penelitian

2 Kurnia Toha, Ka. Pusat Hukum dan Humas BPN, BPN nyatakan 4,8 juta ha lahan terlantar, Harian Media Indonesia, 25 September 2012: hlm. 4

3 Ida Nurlinda, Penataan Ruang yang mendukung Pengendalian Alih Fungsi Lahan Pertanian, Makalah pada Simposium Nasional Pertanahan di Indonesia pada Abad 21, Badan Kerja Sama (BKS) Fakultas Hukum Negeri
Secara keseluruhan tanah terlantar juga menyebabkan krisis tanah secara fisik, tanah terlantar menyebabkan erosi yang terjadi semakin besar dan merusak kualitas tanah. Secara jangka panjang, tanah terlantar juga menyebabkan hilangnya kesuburan tanah, rusaknya siklus hara, dan menipisnya lapisan organik tanah ${ }^{4}$.

Pengaturan mengenai penertiban tanah terlantar sebenarnya sudah lama ada. Di era orde baru, seiring maraknya pembangunan kawasan perumahan dan permukiman diawal tahun 1980an, indikasi tanah yang diterlantarkan oleh pemiliknya, mulai muncul, mengingat banyaknya pengembang (developer) kawasan perumahan yang tidak atau belum memanfaatkan tanahtanah yang dikuasainya untuk digunakan sesuai dengan peruntukannya (kawasan perumahan atau kawasan industri). Hal ini tentu saja ironis dan bertentangan dengan rasa keadilan, asas fungsi sosial atas tanah dan peran tanah dalam mewujudkan kesejahteraan rakyat.

Dalam konsideran menimbang, ditegaskan bahwa ditetapkannya PP No 11 tahun 2010 dikarenakan kondisi penelantaran tanah semakin menimbulkan kesenjangan sosial, kesenjangan ekonomi, kesejahteraan sosial serta menurunkan kualitas lingkungan. Lebih lanjut, dalam penjelasan umum PP No. 11 tahun 2010 dinyatakan bahwa kondisi banyaknya tanah terlantar perlu diatasi dengan melakukan penataan kembali untuk mewujudkan tanah sebagai sumber kesejahteraan, untuk mewujudkan kehidupan yang lebih berkeadilan, menjamin keberlanjutan sistem kemasyarakatan dan kebangsaan Indonesia serta memperkuat harmoni sosial. Selain itu, optimalisasi pengusahaan, penggunaan, pemanfaatan semua tanah di wilayah Indonesia diperlukan untuk meningkatkan kualitas lingkungan hidup, mengurangi kemiskinan dan menciptakan lapangan kerja serta untuk meningkatkan ketahanan pangan dan energi.

Terkait dengan perlunya peningkatan ketahanan pangan, maka penertiban dan pendayagunaan tanah merupakan sesuatu hal yang penting. PP No. 11 Tahun 2010 dan UU No.

seluruh Indonesia dengan BPN, Jakarta, 13 Desember 2011: hlm. 1

4 Hardjowigeno S., dkk. 2001. Kesesuaian Lahan dan Perencanaan Tataguna Tanah.Jurusan Tanah Fakultas Pertanian Institut Pertanian Bogor. 
41 Tahun 2009 tentang Perlindungan Lahan Pertanian Pangan Berkelanjutan, yang di dalamnya menegaskan bahwa negara menjamin hak atas pangan sebagai hak asasi setiap warga negara, lahir untuk mencegah alih fungsi lahan pertanian serta mencegah timbulnya tanah terlantar. Namun tentunya praktek di lapangan perlu dilaksanakan dengan koordinasi yang baik antar instansi terkait dengan tugas-tugas tersebut, baik secara vertikal maupun secara horizontal seperti instansi pertanahan, Bappeda, pertanian, perkebunan, kehutanan dan sebagainya, sebelum menetapkan status tanah.

Di Provinsi Jawa Barat, jumlah tanah terlantar dan tanah pertanian yang mengalami alih fungsi lahan cukup banyak. Hal ini dapat difahami mengingat kebutuhan tanah di daerah Provinsi Jawa Barat sangat tinggi, terutama di wilayah-wilayah sekitar DKI Jakarta, sangat ironis dengan fakta penelantaran tanah-tanah perkebunan di sekitar Provinsi Jawa Barat. Fakta tersebut jelas bertentangan dengan asas fungsi sosial atas tanah yang terkandung dalam Pasal 6 UUPA, beberapa diantara lokasi tanah terlantar tersebut terletak di Kabupaten Tasikmalaya. Kabupaten Tasikmalaya merupakan salah satu dari 17 kabupaten yang ada di wilayah Provinsi Jawa Barat. Kabupaten Tasikmalaya mempunyai luas wilayah $2.563,35 \mathrm{~km} 2$, terdiri atas 39 Kecamatan, 351 Desa. Total penduduk berdasarkan sensus penduduk pada tahun 2010 berjumlah 1.675.554 jiwa, dengan tingkat kepadatan $637 \mathrm{jiwa} / \mathrm{km}^{5}$. Kabupaten ini terletak di tenggara wilayah Priangan, dan merupakan kabupaten paling besar serta berperan penting di wilayah Priangan Timur. Sebagian besar wilayah kabupaten ini merupakan daerah hijau terutama pertanian, perkebunan dan kehutanan. Sektor pertanian merupakan sektor yang dominan dan menjadi motor penggerak perekonomian Kabupaten Tasikmalaya selain sentra industri kerajinan tangan dan sentra bordir. Dengan demikian, petani merupakan mayoritas penduduk di Kabupaten Tasikmalaya. Perekonomian Kabupaten Tasikmalaya selain bertumpu pada sektor-sektor di atas, juga berkembang dengan adanya usaha-usaha peternakan dan budi daya perikanan.

Mengingat kegiatan ekonomi masyarakat Kabupaten Tasikmalaya yang sangat bertumpu pada ketersediaan tanah, maka timbulnya tanahtanah terlantar sangat menganggu upaya

\footnotetext{
${ }^{5}$ Kabupaten Tasikmalaya dalam Angka, 2011: hlm. 3
}

mensejahterakan perekonomian dan kehidupan masyarakat Kabupaten Tasikmalaya tersebut. Untuk itu dilakukannya penelitian ini di Kabupaten Tasikmalaya mempunyai arti yang strategis dan signifikan, untuk melihat penerapan ketentuan PP No. 11 Tahun 2010 di Kabupaten Tasikmalaya. Berdasarkan latar belakang tersebut, masalah dapat diidentifikasikan sebagai berikut :

1. Bagaimanakah mekanisme penetapan tanah terlantar berdasarkan PP No. 11 Tahun 2010 tentang Penertiban Dan Pendayagunaan Tanah Terlantar, dilaksanakan di Kabupaten Tasikmalaya, dan koordinasi dengan instansi lain ?

2. Bagaimanakah dampak dari diterapkannya PP No. 11 Tahun 2010 tentang Penertiban Dan Pendayagunaan Tanah terhadap kebijakan pengelolaan tanah pertanian di Kabupaten Tasikmalaya ?

3. Hal-hal apakah yang dapat direkomendasikan, termasuk program bagi perbaikan dan perlindungan lahan pertanian bagi instansi-instansi terkait dengan penertiban dan pendayagunaan tanah terlantar?

\section{METODE}

Penelitian ini menggunakan pendekatan juridis empiris (juridis sosiologis), yaitu menggunakan data lapangan sebagai data utamanya dan kemudian didukung data kepustakaan sebagai data sekunder. Dalam konteks hukum, data sekunder tersebut baik berupa bahan hukum primer (peraturan perundang-undangan yang terkait), bahan hukum sekunder (literatur yang terkait) maupun bahan hukum tersier (kamus hukum dan indeksasi peraturan perundang-undangan yang terkait).

Dari sisi sifat penelitian, penelitian ini bersifat deskripsi analitis, yaitu memaparkan data sebagaimana adanya untuk kemudian dilakukan analisis terhadap data tersebut berdasarkan asasasas hukum dan kaidah-kaidah hukum yang relevan. Deskriptif analisis digunakan untuk memaparkan data setelit mungkin tentang suatu keadaan atau gejala yang ada dan dimaksudkan untuk membantu dan memperkuat asas hukum, kaidah hukum yang berhubungan dengan materi penelitian. Penelitian deskriptif analitis yang bertujuan menggambarkan, menelaah, dan menganalisis secara sistematis suatu fakta tentang keadaan tertentu, dimana metode ini 
memiliki tujuan untuk memberikan gambaran yang sistematis. faktual serta akurat dari objek penelitian itu sendiri. Dalam hal ini mengenai ; Pengaturan tanah terlantar lahan HGU (Perkebunan) Kabupaten Tasikmalaya dikaitkan dengan Peraturan Pemerintah No 11 tahun 2010 tentang Penertiban dan Pendayagunaan Tanah Terlantar.

Tahapan penelitian ini meliputi penelitian lapangan (field research) yaitu penelitian yang dilakukan untuk memperoleh data primer dari lapangan, dari para pelaksana peraturan dan kebijakan mengenai penertiban dan pendayagunaan tanah-tanah terlantar khususnya di Kabupaten Tasikmalaya, setelah berlakunya PP No. 11 Tahun 2010; serta melakukan evaluasi atas pelaksanaan kebijakan penertiban dan pendayagunaan tanah terlantar tersebut. Selanjutnya adalah penelitian kepustakaan (Library research) untuk memperkuat hasil yang diperoleh dari lapangan.

Data yang telah terkumpul dianalisis secara normatif kualitatif dan didukung pula dengan analisis normatif kuantitatif untuk mengkaji data yang diperoleh dari lapangan. Dalam penelitian hukum empiris (sosiologis) ini, evaluasi atas kebijakan pemerintah daerah kabupaten Tasikmalaya dilakukan dengan cara metode post ante, yaitu metode evaluasi kebijakan yang dilakukan setelah terbitnya kebijakan. Metode kualitatif adalah suatu cara penelitian yang menghasilkan data deskriptif analitis, yaitu yang dinyatakan oleh narasumber dan responden secara tertulis atau lisan. Narasumber penelitian ini adalah para pejabat instansi pemerintah yang terkait dengan materi penelitian sebagaimana telah dikemukakan di atas, sedangkan responden penelitian ini ditarik secara purposive (bertujuan) yaitu responden yang ditarik berdasarkan/mengacu pada tujuan penelitian yang telah dikemukakan di atas.

Data sekunder yang berupa peraturan perundang-undangan dianalisis dengan menggunakan metode penafsiran hukum dan konstruksi hukum untuk menemukan makna sejati dan hakiki dari dirumuskannya peraturan perundang-undangan tersebut agar mudah memahami dan menganalisisnya ketika diterapkan pada data primer yang telah diperoleh dari penelitian lapangan.

\section{HASIL DAN PEMBAHASAN}

\section{Mekanisme Pelaksanaan PP No. 11 Tahun 2010 tentang Penertiban dan Pendayagunaan Tanah Terlantar di Kabupaten Tasikmalaya, dan koordinasi dengan instansi lain}

Berdasarkan Peraturan Kepala Badan Pertanahan Nasional No. 4 Tahun 2010 tentang Tata Cara Penertiban Tanah Terlantar Jo Peraturan Kepala Badan Pertanahan Nasional No. 9 Tahun 2011 tentang Perubahan Peraturan Kepala Badan Pertanahan Nasional No. 4 Tahun 2010 tentang Tata Cara Penertiban Tanah Terlantar adalah sebagai berikut :

1. Inventarisasi tanah hak atau dasar penguasaan atas tanah yang terindikasi terlantar dilaksanakan melalui :

a. pengumpulan data mengenai tanah yang terindikasi terlantar meliputi data tekstual dan data spasial ${ }^{6}$.

b. pengelompokan data tanah yang terindikasi terlantar yang terhimpun dilakukan menurut wilayah kabupaten/kota dan jenis hak/dasar penguasaan.

c. pengadministrasian data hasil inventarisasi tanah terindikasi terlantar diselenggarakan secara tertib dalam basis data untuk keperluan pelaporan, bahan analisis, dan penentuan tindakan selanjutnya.

2. Identifikasi dan penelitian tanah terindikasi terlantarKepala Kantor Wilayah BPN membentuk Panitia C melakukan identifikasi dan penelitian

3. Peringatan terhadap pemegang hak

Berdasarkan saran pertimbangan panitia $C$ terdapat tanah yang diterlantarkan, Kepala Kantor Wilayah memberitahukan kepada pemegang hak dan sekaligus memberikan peringatan yaitu peringatan pertama, agar dalam jangka waktu 1 (satu) bulan sejak tanggal diterbitkan surat peringatan pemegang hak melakukan tindakan konkret, antara lain mengusahakan, menggunakan dan memanfaakan tanahnya sesuai keadaan

\footnotetext{
${ }^{6}$ Data tekstual meliputi nama dan alamat pemegang hak, nomor, dan tanggal keputusan pemberian hak, npmor, tanggal, dan berakhirnya sertipikat, letak tanah, luas tanah, penggunaan tanah, luas tanah terindikasi terlantar. Data spasial merupakan data grafis berupa peta yang dilengkapi dengan koordinat posisi tanah terindikasi terlantar
} 
atau sifat dan tujuan pemberian haknya. Apabila pemegang hak tidak melaksanakan peringatan dan setelah memperhatikan kemajuan peringatan pertama, Kepala Kantor Wilayah memberikan peringatan tertulis kedua dengan jangka waktu yang sama dengan peringatan pertama. Apabila pemegang hak tidak melaksanakan peringatan dan setelah memperhatikan kemajuan peringatan kedua, Kepala Kantor Wilayah memberikan peringatan tertulis ketiga dengan jangka waktu yang sama dengan peringatan kedua.

4. Penetapan Tanah Terlantar

a. Apabila peringatan ketiga ternyata pemegang hak tidak mematuhi peringatan ketiga, Kepala Kantor Wilayah mengusulkan kepada Kepala Badan Pertanahan Nasional untuk ditetapkan sebagai tanah terlantar

b. Penggunaan tanah tidak sesuai dengan surat keputusan atau dasar penguasaan tanah atau

c. belum mengajukan permohonan hak untuk dasar penguasaan tanah. tanah yang diusulkan untuk ditetapkan sebagai tanah terlantar dinyatakan dalam keadaan status quo sejak tanggal pengusulan sampai diterbitkan penetapan tanah terlantar. Tehadap tanah tersebut tidak dapat dilakukan perbuatan hukum.

d. Kepala Badan Pertanahan Nasional menetapkan Keputusan Penetapan Tanah Telantar atas usulan Kepala Kantor Wilayah Badan Pertanahan Nasional.

Berdasarkan hasil monitoring dan evaluasi yang dilakukan, maka diperoleh data-data sebagaimana berikut ini :

1. bahwa berdasarkan hasil monitoring dan evaluasi Hak Guna UsahaNo. 37/HGU/DA/1987 tanggal 29 September 1987 PT Datar Salam seluas 139,900 Ha. Pada tanggal 15 Februari 2012, telah memanfaatkan dan mengusahakan tanahnya secara optimal dan bertahap dengan cara sebagai berikut :

a. Pemanfaatan tanah sesuai peruntukan penggunaannya $10,0000 \mathrm{Ha}$.

b. Pemanfaatan belum sesuai peruntukan penggunaannya $90,9000 \mathrm{Ha}$.

c. Pembibitan/persemaian tanaman karet0,1000 Ha. d. Kantor, Emplasemen, Jalan seluas 4,000 $\mathrm{Ha}$.

e. Sawah 5,0000 Ha.

f. Tidak bisa dimanfaatkan tanah curam berbatuan 29,9000 Ha (Tanah Cadangan), ditanami pohon Albasiah.

2. bahwa sejak diberi peringatan I dan II Hak Guna Usaha PT Datar Salam telah menguasai seluruh Hak Guna Usaha dan memanfaatkan serta mengelola kembali secara maksimal.

3. bahwa PT Datar Salam dalam mengusahakan dan melaksanakan kegiatan kebun mengacu kepada ketentuan dan peraturan yang berlaku.

4. bahwa para penggarap dapat dibina menjadi mitra kerja PT Datar Salam dengan bekerja sebagai buruh harian maupun tetap menggarap tumpang sari atas seijin pihak perusahaan.

5. Pihak perusahaan sedang dilakukan penyemprotan hama tanaman/gulma untuk persiapan Replantation di lokasi seluas \pm $90.9 \mathrm{Ha}$.

Kesimpulan hasil monitoring dan evaluasi terhadap Hak Guna Usaha PT Datar Salam setelah Peringatan II. Adalah sebagai berikut :

1. bahwa pada dasarnya PT Datar Salam sudah memanfaatkan Hak Guna Usahnaya walaupun belum seluruhnya dimanfaatkan sesusi peruntukan penggunaannya.

2. bahwa seluruh lahan Hak Guna Usaha sudah dikuasai seluruhnya oleh PT Datar Salam, dan para penggarap sebagai mitra dalam mengelola kebun.

3. bahwa pada saat ini PT Datar Salam sudah menggunakan areal secara maksimal dalam mengelola kebunnya, sehingga lahan tersebut diharapkan tidak terlantar.

Berdasarkan paparan di atas, mekanisme penertiban dan pendayagunaan tanah terlantar berdasarkan Peraturan Kepala Badan Pertanahan Nasional No. 4 Tahun 2010 tentang Tata Cara Penertiban Tanah Terlantar Jo Peraturan Kepala Badan Pertanahan Nasional No. 9 Tahun 2011 tentang Perubahan Peraturan Kepala Badan Pertanahan Nasional No. 4 Tahun 2010 tentang Tata Cara Penertiban Tanah Terlantar, sudah dilaksanakan sampai pada tahap Peringatan I dan II serta monitoring dan evaluasi.

Sementara itu apabila melihat Undangundang No. 18 Tahun 1984 tentang Perkebunan, kemitraan antara PT Datar Salam dengan masyarakat penggarap sebanyak 300 penggarap 
dengan seijin/dan sepengetahuan perusahaan, sudah sesuai dengan isi ketentuan Pasal 22 ayat

(1) :

"bahwa Perusahaan perkebunan
melakukan kemitraan yang saling
menguntungkan, saling menghargai,
saling bertanggungjawab, saling
memperkuat dan saling ketergantungan
dengan pekebun, karyawan, dan
masyarakat sekitar perkebunan".

Peran perguruan tinggi untuk melakukan penelitian sudah sesuai dengan isi ketentuan Pasal 35, Pasal 36, dan Pasal 37 Undang-undang No. 18 Tahun 2004 tentang Perkebunan, yang pada intinya menyatakan bahwa penelitian dan pengembangan perkebunan dapat dilakukan oleh perguruan tinggi.

\section{Dampak dari diterapkannya PP No. 11 Tahun 2010 tentang Penertiban dan Pendayagunaan Tanah Terlantar terhadap kebijakan pengelolaan tanah pertanian di Kabupaten Tasikmalaya}

Indonesia sebagai negara agraris perlu menjamin penyediaan lahan pertanian pangan secara berkelanjutan sebagai sumber pekerjaan dan penghidupan yang layak bagikemanusiaan dengan mengedepankan prinsip kebersamaan, efisiensi, berkeadilan, berkelanjutan, berwawasan lingkungan dan kemandirian, serta dengan menjaga keseimbangan, kemajuan, dan kesatuan ekonomi nasional. Berdasarkan Undang-undang No. 41 Tahun 2009 tentang Perlindungan Lahan Pertanian Pangan Berkelanjutan, Pasal 1 angka 2 menyebutkan bahwa lahan pertanian adalah bidang lahan yang digunakan untuk usaha pertanian.

Pengujian dan evaluasi tanah terlantar di Kabupaten Tasikmalaya menunjukkan hasil bahwa besaran tanah yang terindikasi sebagai tanah terlantar tidak berpengaruh signifikan terhadap kebijakan pengelolaan tanah pertanian di Kabupaten Tasikmalaya. Tidak berpengaruh nyata ini disebabkan jumlah lahan pertanian yang terkait langsung dengan tanah terlantar sangat sedikit jumlahnya. Dari 4 (empat) lahan yang terindikasi terlantar, 2 (dua) diantaranya dibatalkan oleh Kanwil BPN Jabar sebagai tanah terindikasi terlantar karena status tanah pemerintah. Sebagaimana diketahui, bahwa tanah tanah yang dikuasai pemerintah baik secara langsung maupun tidak langsung dan sudah berstatus maupun belum berstatus Barang Milik Negara/Daerah pemerintah tidak dapat digolongkan sebagai tanah terlantar ${ }^{7}$. Selanjutnya, 2 (dua) lahan yang bermasalah merupakan lahan yang dikelola oleh PT. Genteng Marba dan PT. Datar Salam merupakan lahan perkebunan. Lahan tersebut memiliki luas lahan 383,099 Ha dengan pengelolaan oleh PT. Genteng Marba dan 139,9000 Ha dengan pengelolaan oleh PT. Datar Salam, sehingga total keseluruhan menjadi $522,999 \mathrm{Ha}$. Dari luas lahan tersebut rata-rata luas lahan yang bermasalah berkisar $25 \%$ dari total luas lahan yang dikelola. Hal inilah yang membuat pengaruh PP No 11 Tahun 2010 terhadap jumlah luas lahan pertanian tidak berpengaruh signifikan.

Pertanian dalam arti luas meliputi semua kegiatan usaha dalam reproduksi flora dan fauna, secara sempit pertanian dirumuskan sebagai ilmu dan seni mengusahakan tanah, rumusan pertanian secara sempit tersebut menekankan pada produksi tanaman dalam pertanian. Dalam ruang lingkup yang sempit pertanian dapat dapat diartikan sejenis proses produksi yang khas yang didasarkan atas proses-prroses pertumbuhan tanaman dan hewan. Para petani mengatur dan menggiatkan pertumbuhan tanaman dan hewan itu dalam usaha tani ( farm). Kegiatan-kegiatan produksi di dalam setiap usaha tani merupakan suatu bagian usaha (business), dimana biaya dan pernerimaan adalah penting. Atas dasar pengertian di atas, maka definisi lahan pertanian meliputi lahan pada tanah perkebunan. Salah satu diantaranya adalah lahan yang dikelola oleh PT. Genteng Marba dan PT. Datar Salam. Dengan kondisi ini, maka PP No. 11 Tahun 2010 berpotensi mengalihfungsikan lahan pertanian.

Berkaitan dengan UU No. 41 Tahun 2009 tentang Perlindungan Lahan Pertanian Pangan Berkelanjutan, maka sudah seharusnya PP No. 11 Tahun 2010 mampu menjadi pendorong serta pengendali keberadaan lahan pertanian. Dalam konteks pendorong, PP No. 11 Tahun 2010 sudah seharusnya mampu mengembangan lahan pertanian sehingga produktivitas lahan pertanian menjadi semakin baik. Hal ini yang menjadi salah satu kelemahan dalam PP No. 11 Tahun 2010, kriteria tanah terlantar masih mengacu pada luas lahan yang tidak sesuai dan tidak tergarap ${ }^{8}$. Disini titik kelemahan PP No. 11 Tahun 2010 bahwa luas

\footnotetext{
7 Pasal 3b PP No. 11 Tahun 2010

8 Peraturan Kepala Badan Pertanahan Nasional No. 9 Tahun 2011.
} 
lahan tidak mengambarkan kondisi kesuburan tanah, sangat mungkin bahwa kondisi lahan memiliki kelemahan semisal lapisan tanah bagian A sangat tipis kondisi ini sangat tidak produktif untuk lahan pertanian, bahkan bisa jadi tidak dapat untuk ditanami. Dengan kondisi ini, maka kriteria luas lahan yang tidak tergarap tidak dapat dijadikan dasar bagi penentuan tanah terlantar. Berdasar paparan tersebut, maka PP No. 11 Tahun 2010 belum dapat menjadi instrumen pengendali sebaliknya PP ini berpotensi dalam melemahkan semangat UU No 41 Tahun 2009.

Kondisi sebaliknya PP No. 11 Tahun 2010 juga tidak dapat berfungsi sebagai pendorong atau stimulan bagi perkembangan produktivitas pertanian. Sudah selayaknya dalam setiap perumusan PP mampu memberikan dorongan dan rangsangan, serta pengendali bagi objek yang akan ditujunya. Hal ini terlihat dari kriteria yang dipakai dalam menentukan tanah terlantar. Kriteria luas lahan yang tergarap, tidak dapat memberikan gambaran berapa produktivitas sebenarnya yang dapat dicapai dari proses pengelolaan lahan. Sebagai contoh, tanaman karet dengan umur 3 tahun akan memberikan hasil getah karet 6 ton/ha/tahun jika di tanam pada kriteria kesesuaian lahan tingkat S2. Berbeda jika di tanami pada tanah dengan tingkat kesesuaian lahan S1, maka hasil tanaman karet akan memberikan hasil produksi 9 ton/ha/tahun. Dengan kondisi ini, maka sudah seharusnya kriteria tanah terlantar harus diubah dari kriteria luas lahan menjadi tolak ukur produktivitas lahan. Tolak ukur produktivitas akan memberikan gambaran yang lebih adil bagi masyarakat dan pengusaha serta elemen pengendali yang efektif bagi pemerintah. Tolak ukur ini juga memberikan gambaran yang lebih real dari kriteria luas lahan.

\section{Rekomendasi, termasuk program bagi perbaikan dan perlindungan lahan pertanian bagi instansi-instansi terkait dengan penertiban dan pendayagunaan tanah terlantar}

Upaya penertiban dan pendayagunaan tanah terlantar tidak akan berhasil jika tidak dilakukan secara bersama-sama dan berkesinambungan antara instansi-instansi pemerintah yang tugasnya terkait dengan tugastugas penertiban dan pendayagunaan tanah terlantar. Baik instansi-instansi yang terkait secara horizontal maupun secara vertikal. Sesuai dengan ketentuan Pasal 10 UU No. 32 Tahun 2004 tentang Pemerintahan di Daerah, kewenangan di bidang pertanahan merupakan kewenangan yang dijalankan secara otonomi oleh Pemerintah Daerah. Namun demikian berbagai peraturan perundang-undangan di bidang pertanahan menunjukkan otonomi di bidang pertanahan dijalankan secara setengah hati. Hal tersebut nampak misalnya pada Keppres No. 34 Tahun 2003 tentang Kebijakan Pertanahan Nasional.

Mengingat banyaknya instansi yang terkait (secara langsung maupun tidak langsung) dengan pelaksanaan penertiban dan pendayagunaan tanah terlantar, maka beberapa hal dapat direkomendasikan kepada instansi-instansi tersebut:

1. Instansi pertanahan, baik Badan Pertanahan Nasional (BPN) maupun Kantor Wilayah (Kanwil) BPN di provinsi, seyogianya melaksanakan kewenangan otonomi di daerah di bidang pertanahan. Hal ini selain merupakan amanat dari UU No. 32 Tahun 2004 tentang Pemerintahan Daerah, juga akan memudahkan pengawasan dan pengendalian untuk mencegah terjadinya tanah terlantar. Penelitian atas tanah yang diindikasikan terlantar di Kabupaten Tasikmalaya misalnya, baik tanah terlantar P.T. Datar Salam maupun P.T. Genteng Marba, keduanya mengalami proses panjang yang memperpanjang dan memperlambat proses penetapan tanah terlantar kedua tanah itu. Hal ini disebabkan Kantor Pertanahan Kabupaten Tasikmalaya tidak punya kewenangan untuk menetapkan tanah terlantar, bahkan semua data yang terkait dengan tanah yang diindikasikan terlantar pun dialihkan ke Kanwil BPN Provinsi Jawa Barat, untuk dianalisis dan selanjutnya diajukan ke BPN untuk ditetapkan sebagai tanah terlantar. Pelimpahan urusan pertanahan ke tingkat pemerintahan yang paling bawah, dalam hal ini kabupaten/kota akan mengefektifkan penguasaan dan penggunaan tanah, karena pemerintahan di tingkat kabupaten/kota merupakan perangkat pemerintahan yang paling mengetahui kondisi riel wilayah pemerintahannya.

2. Bappeda baik tingkat provinsi maupun di tingkat kabupaten/kota seharusnya berkoordinasi dengan Dinas Tata Ruang dan Cipta Karya (Distarcip) untuk menterjemahkan dan menjalankan Rencana Tata Ruang Wilayah (RTRW) yang telah 
ditetapkan agar tidak terjadi tanah diterlantarkan disebabkan tidak sesuainya kondisi tanah dengan penetapan peruntukan dan penggunaan tanah yang telah ditetapkan dalam RTRW suatu wilayah, sebagaimana terjadi pada kasus tanah terlantar yang dimiliki oleh P.T. Genteng Marba. Selain itu, sebagai lembaga yang merencanakan pembangunan suatu wilayah, Bappeda seharusnya membuat dan mengarahkan program-program pembangunan sebagai pengejawantahan visi misi dan tujuan suatu daerah yang sesuai dengan kondisi dan kualitas lahan yang ada di wilayahnya, termasuk kemampuan penduduk untuk mengolah dan memanfaatkan tanah tersebut, sehingga tanah dapat didayagunakan secara optimal dan efisien.

3. Pelaksanaan penertiban dan pendayagunaan tanah terlantar harus dilakukan dalam kerangka reforma agraria (pembaruan agraria), yang terintegrasi ke dalam Program Strategis Pertanahan, yaitu9
a. Reforma agraria;
b. Pengendalian pertanahan dan pemberdayaan masyarakat dan penertiban tanah terlantar;
c. Penyelesaian sengketa pertanahan;
d. Percepatan legalisasi aset tanah masyarakat;
e. Pengembangan akses masyarakat pada penguasaan dan pelayanan pertanahan melalui Kantor Pertanahan bergerak, Larasita.

Dengan demikian upaya penertiban tanah terlantar harus ditujukan untuk mendayagunakannya untuk tujuan negara yang hakiki, yaitu mewujudkan kesejahteraan seluruh rakyat Indonesia, dengan menjalankan programprogram yang dapat membuka akses rakyat terhadap tanah dan sumber daya alam lainnya. Selain untuk mewujudkan kesejahteraan, pada akhirnya juga diharapkan dapat berkontribusi dalam mewujudkan keadilan, terutama keadilan dalam penguasaan, pemilikan, penggunaan dan pemanfaatan tanah (P4T).

Mochtar Kusumaatmadja memaknai hukum dalam 2 persepsi dasar, yaitu hukum sebagai gejala normatif dan hukum sebagai gejala sosial. Sebagai gejala normatif, hukum mempunyai unsur

\footnotetext{
9 Joyo Winoto, Tanah untuk Kesejahteraan Rakyat, www.bpn.go.id didownload tanggal 23 Juni 2010
}

asas dan kaidah; sementara sebagai gejala sosial, mempunyai unsur lembaga dan proses. Keempat unsur ini hanya dapat dibedakan tetapi tidak dapat dipisahkan. Kendala pelaksanaan hukum seringkali terjadi pada tataran hukum sebagai gejala sosial, yaitu terkait dengan penegakan hukum itu sendiri. Dengan demikian, dalam kaitannya dengan penertiban dan penggunaan tanah terlantar, implementasi PP No. 11 Tahun 2010 menjadi kunci untuk terwujudnya keadilan agraria sebagai tujuan akhir dari reforma agraria.

\section{SIMPULAN}

Mekanisme penetapan tanah terlantar kurang berkoordinasi dengan instansi lain , hanya berjenjang di instansi pertanahan dan prosedur sangat panjang menimbulkan penantian yang cukup panjang dalam pelaksanaan PP No 11 Tahun 2010, sehingga terjadi ketidak pastian hukum

Dampak penerapan PP No. 11 Tahun 2010 kurang objektif dalam menilai kriteria produktivitas lahan khususnya berkaitan dengan menjaga keberadaan tanah pertanian di Kabupaten Tasikmalaya

Direkomedasikan kepada instansi pertanahan agar melaksanakan UU No. 32 Tahun 2004 tentang Pemerintahan di Daerah, Bappeda seharusnya berkoordinasi dengan Dinas Tata Ruang dan Cipta Karya untuk menjalankan Rencana Tata Ruang wilayah (RTRW), implementasi PP No. 11 Tahun 2010 menjadi kunci untuk terwujudnya keadilan agraria sebagai tujuan akhir dari reforma agraria.

\section{DAFTAR PUSTAKA}

\section{Buku-buku}

Mulyadi, Kartini. 2004. Gunawan Widjaja, Seri Hukum Harta Kekayaan Hak-hak atas Tanah, Kencana Prenada Media Grup, Jakarta, 2004

Nurlinda, Ida. 2011. Penataan Ruang yang mendukung Pengendalian Alih Fungsi Lahan Pertanian, Makalah pada Simposium Nasional Pertanahan di Indonesia pada Abad 21, Badan Kerja Sama (BKS) Fakultas Hukum Negeri seluruh Indonesia dengan BPN, Jakarta, 13 Desember 2011 
Winoto, Joyo. 2010. Tanah untuk Kesejahteraan Rakyat, www.bpn.go.id didownload tanggal 23 Juni 2010

\section{Peraturan Perundang-undangan}

Undang-undang No 5 Tahun 1960 tentang Peraturan Dasar Pokok-pokok Agraria

Undang-undang No. 18 Tahun 2004 tentang Perkebunan

Undang-undang No. 32 Tahun 2004 tentang Pemerintahan di Daerah

Undang-undang No. 41 Tahun 2009 tentang Perlindungan Lahan Pertanian Pangan Berkelanjutan

Peraturan Pemerintah No. 40 Tahun 1996, Hak Guna Usaha, Hak Guna Bangunan dan Hak Pakai atas Tanah
Peraturan Pemerintah No 11 Tahun 2010 tentang Penertiban dan Pendayagunaan Tanah Terlantar

Keputusan Presiden No. 34 Tahun 2003 tentang Kebijakan Pertanahan Nasional

Peraturan Kepala Badan Pertanahan Nasional No. 4 Tahun 2010 tentang Tata Cara Penertiban Tanah Terlantar

Peraturan Kepala Badan Pertanahan Nasional No. 9 Tahun 2011 tentang Perubahan Peraturan Kepala Badan Pertanahan Nasional No. 4 Tahun 2010 tentang Tata Cara Penertiban Tanah Terlantar

Sumber Lain

Kabupaten Tasikmalaya dalam Angka, 2011

Toha, Kurnia. 2012. Ka. Pusat Hukum dan Humas BPN, BPN nyatakan 4,8 juta ha lahan terlantar, Harian Media Indonesia, 25 September 2012 